\title{
Profiles in Cardiology
}

This section edited by J. Willis Hurst, M.D., and W. Bruce Fye, M.D., M.A.

\section{Thomas Woodward Smith}

\author{
Roman W. DeSANCTIS, M.D. \\ Cardiac Unit, Massachusetts General Hospital, and Harvard Medical School, Boston, Massachusetts, USA
}

The cardiological world lost one of its giants with the death of Dr. Thomas W. Smith on March 23, 1997. He was 61 years old.

A native of Akron, Ohio, Dr. Smith obtained his undergraduate education at Harvard University, graduating cum laude in 1958. After college he served for 3 years as a line officer in the United States Navy. He was stationed on a destroyer, and it was during this time that he was exposed to asbestos, which in later years caused the mesothelioma that ultimately claimed his life.

He returned from the Navy to enter Harvard Medical School, graduating magna cum laude in 1965 . He completed his internship, residency, and fellowship training at the Massachusetts General Hospital (MGH), joining the staff of that institution in 1969. In 1974 he was selected by Dr. Eugene Braunwald to become Chief of the Cardiovascular Division at the Peter Bent Brigham Hospital (now Brigham and Women's Hospital), a position that he held until his death. He was also Professor of Medicine, jointly at Harvard Medical School and in the combined Harvard-MIT Division of Health Sciences and Technology.

In 1967, Dr. Smith joined the laboratory of Dr. Edgar Haber at the MGH, initiating a distinguished career in basic and clinical investigation that continued throughout his lifetime. It was there that he developed an enduring love affair with the digitalis glycosides. He was undoubtedly the leading investigator in the field of digitalis in the last half of this century. $\mathrm{He}$ even possessed an original edition of William Withering's historic treatise on the foxglove!

Address for reprints:

Roman W. DeSanctis, M.D.

Massachusetts General Hospital

Ambulatory Care Center

15 Parkman Street, Suite 467

Boston, MA 02114-3117, USA

Received: March 24, 1998

Accepted: March 24, 1998
In a medical classic, Dr. Smith reported in 1970 with Haber and Butler the determination of serum digoxin concentrations using a radioimmunoassay. ${ }^{I}$ This measurement is now used worldwide in common clinical practice and has been largely responsible for a marked reduction in the incidence of digitalis toxicity, as well as helping enormously in the day-to-day management of patients taking digoxin.

This seminal work led to the development of binding antibodies to the digitalis glycosides for use in life-threatening digitalis toxicity. In 1976, he and his colleagues reported the reversal of nearly fatal digitalis toxicity using the Fab fragment of the antibodies against digitalis. ${ }^{2}$ This compound $\left(\right.$ Digibind $\left.^{\circledR}\right)$ is now available for clinical use and has been responsible for reversing many cases of severe, potentially lethal glycoside toxicity.

From these investigations, Dr. Smith moved on with his colleagues to a study of the cellular mechanisms of the action of digitalis, using cultured chick myocytes. ${ }^{3}$ In recent years, Dr. Smith was involved in basic molecular studies involving adrenergic and cholinergic signaling within the heart, and mechanisms of excitation-contraction coupling. He had recently turned his attention to the action of endothelial compounds-especially endothelin and nitric oxide—on cardiac cells. ${ }^{4}$

Dr. Smith was also one of the principal investigators of the "DIG" (Digitalis Investigation Group) study, which clarified the role of digoxin in congestive heart failure. ${ }^{5}$ This study, published one month before his death, showed that although digoxin did not improve overall survival, it reduced the rate of hospitalization in patients with heart failure. ${ }^{5}$

In all, Dr. Smith was the author or co-author of approximately 240 original papers and 150 symposia, book chapters, and editorials. He also wrote and edited several books, including the modern classic on digitalis. ${ }^{6}$

Dr. Smith was a true academic triple threat. He was a superb teacher, and took pride-perhaps above all other of his professional accomplishments-in nurturing and mentoring scores of brilliant young trainees, many of whom now occupy major positions of leadership in cardiology throughout the world. In addition, he was a gifted clinician.

Dr. Smith was very much interested in medical education. He served as Chairman of the Curriculum Committee at Har- 


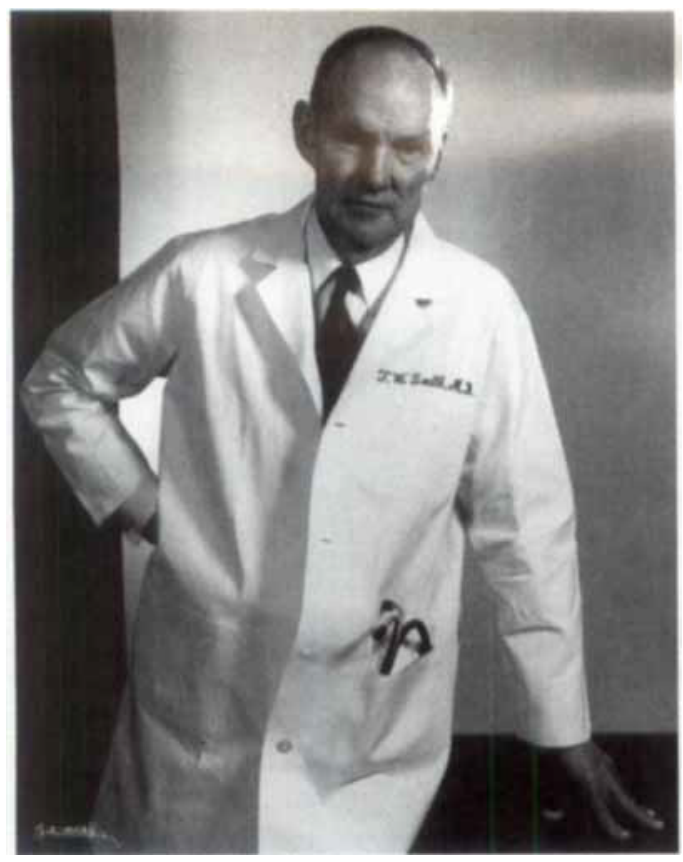

Fig. 1 Thomas Woodward Smith, M.D. (1936-1997). Photograph provided by Mrs. Smith.

vard Medical School and was one of the driving forces behind the so-called "New Pathway" curriculum, which has set the direction of medical education for the next century. He served as President of the Association of University Cardiologists and was very active in the American Heart Association, for which he chaired many important committees through the years, particularly those related to publications, research, and training.

He was widely sought after as a lecturer and visiting professor and received numerous prestigious awards, including a Merit award from the National Institutes of Health for his research achievements. He was a member of the Association of American Physicians and a Master of the American College of Physicians.

But Dr. Smith was also a worldly man, with many interests outside of medicine. He had a keen wit and a fine sense of humor and was a scintillating conversationalist because of his wide range of knowledge stemming from an insatiable curiosity about anything and everything. He loved literature, music, sports, good food, and good wine. And he had a special love for golf, spending as much time as his busy schedule would allow at The Country Club in pursuit of the little white ball.

I cannot end this profile on Dr. Smith without commenting on the dignity and courage with which he conducted himself during his illness. Despite the fact that he became steadily more frail and weak, both from his underlying disease and its treatment, he never complained or indulged in self-pity, nor did he allow anyone else to feel sorry for him. He was firmly in control of his department right up to the time of his death, living every day to its maximum, meeting every commitment. He was inspirational beyond expression.

One of Dr. Smith's great good fortunes in life was his marriage to his wife, Sherley, who was not only a wonderful mate and a pillar of strength during this illness, but also has pursued her own successful career as an educator. The Smiths have three children, Julie, Geoffrey, and Allison, and four grandchildren.

Shortly before his death, a special symposium in Dr. Smith's honor was held at the Brigham and Women's Hospital. At that time, The Thomas Smith Fellowship in Cardiovascular Research was established, which will honor appropriately and in perpetuity this great man who was taken from us much too soon.

\section{References}

1. Smith TW, Butler VP Jr, Haber E: Determination of therapeutic and toxic serum digoxin concentrations by radioimmunoassay. $N$ Engl JMed 1969;281:1212-1216

2. Smith TW, Haber E, Yeatman L, Butler VP Jr: Reversal of advanced digoxin intoxication with Fab fragments of digoxin-specific antibodies. NEngl J Med 1976;294:797-800

3. Barry WH, Biedert S, Miura DS, Smith TW: Changes in cellular $\mathrm{Na}, \mathrm{K}$, and Ca contents, monovalent cation transport rate, and contractile state during washout of cardiac glycosides from cultured chick heart cells. Circ Res 1981;49:141-149

4. Gross WL, Bak MI, Ingwall JS, Arstall MA, Smith TW, Balligand J-L, Kelly RA: Nitric oxide inhibits creatine kinase and regulates rat heart contractile reserve. Proc Natl Acad Sci USA 1996;98: 5604-5609

5. The Dititalis Investigation Group: The effect of digoxin on mortality and morbidity in patients with heart failure. N Engl J Med 1997; 336:525-533

6. Smith TW (Ed.): Digitalis glycosides. Orlando: Greene \& Stratton, Inc., 1986 